\title{
The Determinants of Stock Returns in the Emerging Market of Kenya: An Empirical Evidence
}

\author{
Muinde Patrick Mumo ${ }^{1}$ \\ ${ }^{1}$ Department of Learning \& development, Kenya School of Government, Lower Kabete, Nairobi, Kenya \\ Correspondence: Muinde Patrick Mumo, Department of Learning \& development, Kenya School of Government, \\ P.O. Box 23030 -00604, Lower Kabete, Nairobi, Kenya. Tel: 254-723-584-928. E-mail: pmmumo@ yahoo.com
}

Received: June 17, 2017

Accepted: June 28, 2017

Online Published: July 20, 2017

doi:10.5539/ijef.v9n9p8

URL: https://doi.org/10.5539/ijef.v9n9p8

\begin{abstract}
This study examined the sources of risk factors that determine stock returns in the emerging market of Kenya. The specific objectives were to determine the validity of the Capital Asset Pricing Model (CAPM) and then empirically test for factors that are priced in stock returns in Kenya.

The factors examined are the excess market premium and selected macroeconomic factors including inflation, exchange rates, money supply and short term interest rates. The study utilizes monthly time series data for the period April 1996: December 2016. The CAPM, a multifactor approach and Fama and MacBeth (1973) two-step procedure are used for data analysis.

The study finds that CAPM cannot be rejected and that the market premium is the most important factor in explaining stock return variability in Kenya. Therefore, the study concludes that unlike the recent evidence on the collapse of CAPM in advanced markets, the model can still be validly used for the Kenyan market.
\end{abstract}

Keywords: stock returns, market premium, macroeconomic variables, Nairobi securities exchange and evidence

\section{Introduction}

\subsection{Background}

The question about the determinants of stock returns continues to baffle economists. While much ground has been covered in the recent past, the evidence continues to evolve. From the traditional one factor model of the 1960 s, through the three and four factor models of the 1990s, research is edging towards a five factor model in the $21^{\text {st }}$ century.

The dichotomy of these researches has been on the tradable versus macroeconomic factors. Hsu (2015) argues for the merits of tradable factors over the macroeconomic factors. With tradable factors, it's easy to identify if the model is poorly specified, can hedge against exposure to a particular risk factor, data are observed with higher precision and macroeconomic factors have the disadvantage of being less granular with data at weekly, quarterly or even annual intervals. Data on daily to minute-by-minute maybe found for tradable factors.

On the other continuum, advocates for macroeconomic variables argue that while in true sense it is hard to model purely exogenous factors (like forces of nature such as earthquakes) on stock returns, macroeconomic factors can to a large extent be considered as external forces, and thus exogenous (Chen, Roll \& Ross, 1986). In theory, any systematic changes in variables that affect the economy's pricing operator, or influence dividends, would in turn influence stock market returns. Various studies have therefore examined both tradable and macroeconomic factors.

\subsection{Statement of the Problem}

The fact that emerging markets are the future frontiers of growth and risk diversification to global investors is widely acknowledged. However, the one big challenge that investors have to content with is the absence of quality information on the drivers of stock returns in these markets. This study seeks to proffer a glimpse of literature with data from the Kenyan market.

Studies done on Kenya this far have mainly focused on the relationship between macroeconomic factors and their effects on stock prices (see Muinde, 2017; Kimani \& Mutuku, 2013; Kirui, Wawire, \& Onono, 2014; Ouma \& Muriu, 2014; Ochieng \& Oriwo, 2012; Aroni, 2011; Olweni \& Omondi, 2011; Gituhi, Gekara, \& Muturi, 2015; 
Laichena \& Obwogi, 2015; Kiboi \& Katuse, 2015). In general, these studies report mixed results on the effects of the commonly studied macro variables including inflation, money supply, exchange rates and short-term interest rates.

However, with the longest data set thus far, Muinde (2017) demonstrates that a majority of the OLS findings could be attributed to spurious problems of the time series data utilized. The current study extends these findings to establish the risk factors that determine stock returns in Kenya. Chen et al. (1986) demonstrates that based on some existing theory and/or pre-identified factors, the multifactor model and the Fama and MacBeth (FMB) 1973 two-step procedure could be used to determine the sources of risk factors priced in the stock market.

The specific research questions in this study are:

1) Does CAPM still hold in the emerging market of Kenya?

2) What sources of risk factors are priced in stock returns in the Kenyan market?

\subsection{Objectives of the Study}

The objectives of the study are:

1) To determine if CAPM still holds in the emerging market of Kenya

2) To determine the sources of risk factors that are priced in stock returns in the Kenyan market.

3) If CAPM holds, document stock betas for listed firms at the NSE.

This study contributes to the scantily available empirical evidence on the determinants of stock returns from the emerging markets in Africa. Particularly, it utilizes "an out of sample" data set from Kenya. Besides, the study models macroeconomic factors in addition to the market premium factor. It is hoped that the evidence adduced here shall give insights into the little known Sub-Saharan Africa markets.

The rest of the study is organized into four sections. Section two discusses the relevant literature, section three presents the study methodology, section four present and discusses the findings of the study while section five makes the conclusions.

\section{Relevant Literature}

\subsection{The Determinants of Stock Returns in Emerging Markets}

In general, there is limited literature on the determinants of stock returns in emerging markets largely due to data limitations that impede advanced empirical tests. However, a number of studies have been done in the recent past.

Dasgupta and Glen (1999) examines the factors of E/P ratio, size, value, dividend yield, percentage change of local currency (relative to the US\$) and turnover using data from 19 emerging markets. They find both commonalities and contrary evidence on the determinants of stock returns from emerging markets to those documented in developed markets. The intercept is significant from zero in 12 of the 19 studied markets and $\beta$ coefficients are significant for only nine of the 19 countries. This evidence indicates the failure of CAPM in a majority of these markets, similar to advanced markets.

Further, they report positive and significant size effect for 11 of the 19 markets studied, contrary to negative size effect from advanced markets. The value factor and E/P ratio are significant in six and seven of the 19 markets in the sample respectively. Only three markets show positive effect consistent with Fama and French (1992) for the US market. The E/P effect is positive in six of the seven markets that show significant effect. Dividend yield was significant in seven markets and negative in four of these markets, contradicting Brenan (1970) prediction of a positive effect. But this effect could be negative when taxation is taken into consideration (Dasgupta \& Glen, 1999).

Evidence of turnover (liquidity) effect was found in nine markets of the 19 and the sign was positive. This indicates positive premium for liquidity contrary to positive illiquidity premiums documented in developed markets. Similarly, the foreign exchange effect was positive in nine of the 19 countries with the sign positive except for one that had a negative sign. A further five markets had a negative, though insignificant effect.

Serra (2003) examines the determinants of stock returns using data from 21 emerging markets. She documents that factors of attributes $(\mathrm{B} / \mathrm{M}$ ratio, E/P ratio and Cash flow -to- price $(\mathrm{C} / \mathrm{P})$ ratio) and liquidity factors as the most important factors in the determination of cross section returns. Results based on the base specification indicate negative coefficients for the attribute factors contrary to the evidence from developed markets. However, the negative coefficients for the attribute factors reverse when trailed time trends are used, turning the results to 
be consistent with those documented in advanced markets. The payoffs from liquidity factors are negative and find no size effect, contrasting the evidence from advanced markets.

Fama and French (1998) study 13 markets around the world and document evidence of higher returns for value stocks compared to growth stocks. They find that the difference between the average returns of global portfolios of high and low-to-book market to be $7.68 \%$ per year. Further, the value stocks outperform growth stocks in 12 of the 13 global markets studied. International CAPM fails to explain value premium, but a two factor model that includes a risk premium for relative distress captures value premiums in international returns.

Rouwenhorst (1999) document similar commonality in the qualitative factors that determine stock returns between emerging and advanced markets. He finds emerging markets exhibit momentum, small stocks outperform large stocks and value stocks outperform growth stocks similar to evidence from developed markets. He finds no evidence that high beta stocks outperform low beta stocks. However, he finds a strong cross-sectional correlation between the return factors and share turnover.

Lischewski and Voronkova (2010) examines the market, size, value and liquidity factors for the Polish stock market. They find evidence for the market, size and value factors similar to that of developed market, but find no evidence for liquidity risk premium. Al-Rjoub, Yousef, and Ananzeh (2010) examine the cross-sectional behavior of stock returns for four emerging markets from the Middle East and North Africa (MENA) of Egypt, Jordan, Morocco and Saudi Arabia. They use the "between estimator" panel data regression to test the P/E ratio, B/M ratio, size and beta $(\beta)$. They find the market factor $(\beta)$ is the most important factor in predicting stock return variability in the four markets.

The cumulative empirical evidence from these studies indicates mixed results. Dasgupta and Glen (1999) argues that the investing world would have to spend more time to understand how these markets work to contextualize and interpret correctly the emanating evidence from them. The more fundamental question that needs to be understood is how the tax systems, market microstructure, improvements in market structures and the opening of these markets to foreign investors affect their market behavior.

\subsection{Empirical Evidence}

\subsubsection{The Market Factor}

The market factor is premised on the belief that the stock market will expose investors to a certain degree of market risk that cannot be diversified, has to be hedged and that in equilibrium will be compensated by a risk premium (Sharpe, 1964; Lintner, 1965; and Mossin, 1966).

However, CAPM theory is based on certain key assumptions that if they don't hold will cast doubts on its validity. These assumptions include rational expectations for the asset return $\left(R_{i, t}\right)$, the risk free rate $\left(R_{f, t}\right)$, market return $\left(R_{m, t}\right)$ and any other variable $\left(Z_{i, t}\right)$; a constant beta $(\beta)$, at least through the estimation period; and a holding period that is known, usually one month. Criticism of CAPM in the late 1970s through the 1990s focused on these assumptions.

Despite the criticism against CAPM, it remained a popular model until the emergence of Chen et al. (1986) multifactor model, Fama \& French (1993) 3 factor model and a 4 factor model by Carhart (1997). While recent evidence points to the collapse of CAPM in developed markets, it's not quite clear if the case is the same for emerging markets.

The 3 factor and 4 factor models have gained traction in the recent past, but their generalization into other markets remains in doubt (Artmann, Finter, \& Kempf, 2011). Fama and French (2015) have proposed a 5 factor model. However, the practical applicability of these models isn't feasible for emerging markets due to the relative small size of listed firms in such markets.

Even though CAPM has been found to collapse in developed markets, studies have found that it cannot be rejected in some emerging markets. For instance, Borys (2007) tests for CAPM in the Visegrad countries (Hungary, Czech Republic, Republic of Slovakia and Poland) and finds that she could not reject it for Hungary and the Republic of Slovakia. Dasgupta and Glen (1999) studies 19 emerging markets and they could not reject CAPM in at least seven of those markets. Al-Rjoub et al. (2010) studies 4 MENA countries and finds beta as the most significant factor.

\subsubsection{The Macroeconomic Factors}

Chen et al. (1986) proposed the macroeconomic factors of spread between long and short interest, expected and unexpected inflation, industrial production and spread between high and low grade bonds as sources of risk factors priced in stock returns. From their study, the systematic risk, changes in aggregate consumption and 
changes in oil prices are not priced in the market.

Ericsson and Karlsson (2004) examines 15 factors using a Bayesian approach and proposes that market excess return, size premium, value premium, momentum factor, credit risk spread and possibly industrial production are the factors that ought to be considered in multifactor models.

Menike, Dunusinghe, and Ranasinghe (2015) examines firm specific and macroeconomic factors for both Sri Lanka and the United Kingdom (UK). They report Return on Assets (ROA) and Sales growth rate for Sri Lanka and $\mathrm{E} / \mathrm{P}$ ratio, $\mathrm{B} / \mathrm{M}$ ratio, fixed asset growth rate, size and ROA for $\mathrm{UK}$ as the dominant priced factors. The explanatory power of these factors is enhanced when they control for inflation, Gross Domestic Product (GDP) and exchange rates in both markets, while employment rates and foreign portfolio investment becomes significant for Sri Lanka only.

In the Indian market, a long-run positive relationship between stock prices and money supply and industrial production and a negative relation for inflation has been widely documented (Naik \& Padhi, 2012; Kumar, 2013; Patel, 2012; Pal \& Mittal, 2011; Aurangzeb, 2012). Benakovic and Posedel (2010) finds a positive relation between stock returns and the market index, interest rates, industrial production and oil influence, with inflation showing a negative relation for the Croatian Market.

Mahonye and Mandishara (2014) finds inflation, real income, money supply and exchanges rates as the main determinants of stock returns during the period of the hyper inflation in Zimbabwe. Oyama (1997) finds that sharp increases in stock prices in mid 1990s in Zimbabwe could be explained by movements in monetary aggregates and market interest rates. Eita (2011) finds increase in economic activity and money supply increase stock prices while increase in inflation and interest rates decrease stock prices in Namibia.

In the Nigerian market, expected growth, size, exchange rates, inflation, money supply, real output, interest rates and previous stock returns are found to be the important factors that determine stock returns (Olowoniyi \& Ojenike, 2012; Maku \& Atanda, 2010; Osisanwo \& Atanda, 2012).

In the emerging market of Kenya, empirical evidence is mixed for the commonly studied factors. Muinde (2017) demonstrates the volatility of the macro environment as depicted in Figure 1.

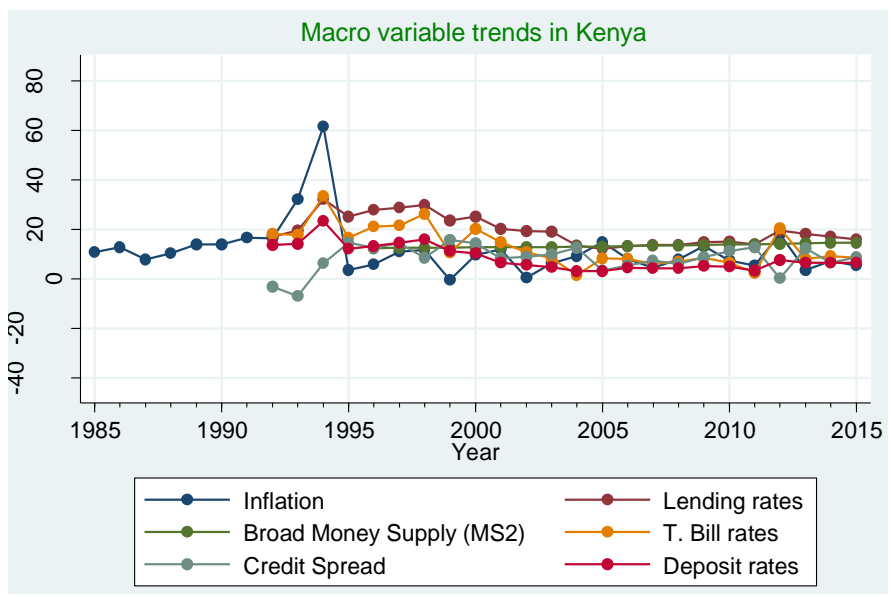

Figure 1. Overview of trends for selected Macro variables in Kenya from the mid 1990s

Source: Muinde, 2017, p. 2.

Evidence on the effect of macro variables in Kenya has been conflicting. Some studies indicate a positive inflation effect on stock returns (Aroni, 2011; Ochieng \& Oriwo, 2012; Ouma \& Muriu, 2014; Kirui et al., 2014; and Kiboi \& Katuse, 2015) contrary to economic theory and intuition, while others report a negative effect (Kamau \& Mutuku, 2013; Gituhi et al., 2015; and Muinde, 2017).

Exchange rates suggests both positive effect (Gituhi et al., 2015; Muinde, 2017) and negative effects (Aroni, 2011; Ouma \& Muriu, 2014; Kirui et al., 2014; Kamau \& Mutuku, 2013; Kiboi \& Katuse, 2015). Exchange rates volatility could affect stock returns on either way depending on whether a country is a net importer or exporter. In Kenya, while the country is overall a net importer, exchange rates is a major source of macroeconomic volatility (Muinde \& Karanja, 2017). 
Money supply has also shown mixed effects for Kenya. Most studies report a positive effect (Ouma \& Muriu, 2014; Aroni, 2011; Gituhi et al., 2015; Kiboi \& Katuse, 2015). However, Muinde (2017) finds that in the absence of a suitable proxy for the intervening variable of industrial production, increase in money supply will be expected to drive inflation and eventually outweigh the money supply positive effects.

The effect of interest rates has also been conflicting. Some studies suggest a positive effect (Gituhi et al., 2015; Muinde, 2017) while others suggest negative effects (Aroni, 2011; Ochieng \& Oriwo, 2012; Kirui et al., 2014; and Kiboi \& Katuse, 2015). Ouma and Muriu (2014) find interest rates as un important factor. Muinde (2017) argues that interest rates has been a key instrument of monetary policy in Kenya. He adduces evidence of possible spurious problems in most of the documented findings on the Kenyan market.

This study examines which of the identified macro variables is a source of risk priced in Kenya in addition to the market premium.

\section{The Methodology}

\subsection{Data Collection, Data Sources and Description of Variables}

This study utilizes a time series data. Daily trading data for all listed firms in Kenya has been obtained from the NSE for the period April 1996: December 2016, and monthly stock returns computed. Monthly Weighted NSE 20 share index and monthly Consumer Price Index (CPI) has been obtained online from the Kenya National Bureau of Statistics (KNBS). Data on changes in money supply and average 91-day Treasury bill rates has been obtained online from the Central Bank of Kenya (CBK).

To apply the Chen et al. (1986) and the FMB procedure, the variables are expressed in return form. Thus the general transformation takes the following form:

$$
\operatorname{InCPI} I_{t}-\operatorname{InCPI}_{t-1}
$$

Other variables have been computed in a similar manner except for short-term interest rate that has been computed as shown below:

$$
\frac{A T B_{t}-A T B_{t-1}}{A T B_{t-1}} * 100
$$

For ease of operation, the variables have been defined and described in Table 1.

Table 1. Definition and description of variables

\begin{tabular}{llc}
\hline Acronyms & Construction of Variables & Data Source \\
\hline InNSER & $\begin{array}{l}\text { Natural logarithm of the weighted average market value of the NSE 20 share index month-end closing prices } \\
\text { (proxy for monthly market prices) }\end{array}$ & KNBS \\
ERm & Excess market premium(the market factor) computed as $\mathrm{R}_{\mathrm{i}, \mathrm{t}}-\mathrm{R}_{\mathrm{f}}$ & \\
InCPI & Natural logarithm for monthly average CPI ( measure of monthly unexpected inflation) & KNBS \\
InMs & Natural logarithm of the monthly average of broad money supply (Ms2 (Note 1)) & CBK \\
InEX & Natural logarithm of the average monthly exchange rate for the Kenya shilling(KES) against the US\$ (US dollar) & CBK \\
ATB & Average monthly 91-day Treasury bill rates (measure of risk free rate, and proxy for short-term interest rates). & CBK \\
\hline
\end{tabular}

NB: KNBS -Kenya National Bureau of Statistics monthly economic indicators reports; CBK -Central Bank of Kenya. All data are available online from the two institutions websites.

\subsection{Sample Size and Sampling Procedure}

The study utilizes data for all firms listed at the NSE for the entire sample period.

\subsection{Data Analysis}

The study first tests for validity of CAPM and then adapts the Chen et al. (1986) multifactor model and applies the FMB procedure. Formerly, CAPM is expressed in equation 1.

$$
E\left(R_{i, t}\right)-R_{f, t}=\beta_{i}\left[E\left(R_{m, t}\right)-R_{f, t}\right]
$$

Where $E\left(R_{i, t}\right)$ is the expected $i^{\text {th }}$ stock return $(i=1, \ldots, N), R_{f, t}$ is the risk-free rate and $E\left(R_{m, t}\right)$ is the expected market return. Empirically, the model can be tested using the following regression equation:

$$
R_{i, t}-R_{f, t}=\alpha_{i}+\beta_{i}\left(R_{m, t}-R_{f, t}\right)+\varepsilon_{i, t}
$$

Where $R_{i, t}-R_{f, t}$ is the excess return on the $i^{\text {th }}$ stock, $R_{m, t}$ is the market return, $\alpha_{i}$ is a constant term, $\beta_{i}$ is the coefficient on the excess market return for each of the $\mathrm{i}^{\text {th }}$ stocks, and $\varepsilon_{\mathrm{i}, \mathrm{t}}$ is the error term. 
According to CAPM prediction, the constant term, $\alpha_{i}$ should be statistically insignificant. The slope coefficient $\beta_{\mathrm{i}}$ should be positive and statistically significant from zero. Moreover, this coefficient is a measure of the stock's risk and should vary among the stocks (Borys, 2007).

The FMB procedure is done in two stage regressions. The first stage involves a set of time series regression of each asset or portfolio return on the factors. This can be expressed as:

$$
\begin{aligned}
& R_{1, t}=\alpha_{1}+\beta_{1, F 1} E R_{m, t}+\beta_{1, F 2} I n C P I_{t}+\beta_{1, F 3} I n E X_{t}+\beta_{1, F 4} I n M s_{t}+\beta_{1, F 5} A T B_{t}+\varepsilon_{1, t} \\
& R_{2, t}=\alpha_{2}+\beta_{2, F 1} E R_{m, t}+\beta_{2, F 2} I_{n C P I}+\beta_{2, F 3} I n E x_{t}+\beta_{2, F 4} I n M s_{t}+\beta_{2, F 5} A T B_{t}+\varepsilon_{2, t} \\
& R_{n, t}=\alpha_{n}+\beta_{n, F 1} E R_{m, t}+\beta_{n, F 2} \operatorname{InCPI}_{t}+\beta_{n, F 3} \operatorname{InEX} X_{t}+\beta_{n, F 4} \operatorname{InMs}_{t}+\beta_{n, F 5} A T B_{t}+\varepsilon_{n, t}
\end{aligned}
$$

Where $\mathrm{R}_{1, \mathrm{t}} \ldots \mathrm{R}_{\mathrm{n}, \mathrm{t}}$ are $\mathrm{n}$ asset or portfolio excess returns over $\mathrm{T}$ periods, $\mathrm{F}_{1, \mathrm{t}} \ldots \mathrm{F}_{\mathrm{m}, \mathrm{t}}$ are $\mathrm{m}$ factors that explain asset/portfolio returns, $\beta_{1} \ldots \beta_{\mathrm{n}}$ are the premia awarded to exposure to each factor, $\epsilon_{1, \mathrm{t}} . . \epsilon_{\mathrm{n}, \mathrm{t}}$ are the error terms.

This time series regressions can be expressed in a matrix form:

$$
R_{n}=F \beta_{n}+\epsilon_{n}
$$

Where $R_{n}$ is a t $x 1$ vector of returns, $F$ is a $x(m+1)$ matrix of factors where all elements in the first column are $1, \beta_{\mathrm{n}}$ is a $(\mathrm{m}+1) \mathrm{x} 1$ vector of factor loadings where all elements in the first row are the intercept $\alpha_{\mathrm{n}}$, and $\epsilon_{\mathrm{n}}$ is a $\mathrm{t} x 1$ vector of errors.

In the second stage, the factor premiums for each factor are calculated using a set of cross-sectional regressions.

$$
\begin{array}{r}
R_{i, 1}=\alpha_{1}+\gamma_{1,1} \hat{\beta}_{i, F 1}+\gamma_{2,1} \hat{\beta}_{i, F 2}+\cdots+\gamma_{m, 1} \hat{\beta}_{i, F m}+\varepsilon_{1} \\
R_{i, 2}=\alpha_{2}+\gamma_{1,2} \hat{\beta}_{i, F 1}+\gamma_{2,2} \hat{\beta}_{i, F 2}+\cdots+\gamma_{m, 2} \hat{\beta}_{i, F m}+\varepsilon_{2} \\
R_{i, T}=\alpha_{T}+\gamma_{1, T} \beta_{i, F 1}+\gamma_{2, T} \hat{\beta}_{i, F 2}+\cdots+\gamma_{m, T} \hat{\beta}_{i, F m}+\varepsilon_{T}
\end{array}
$$

Where $\gamma_{\mathrm{j}, \mathrm{t}}$ terms are regression coefficients, $\widehat{\beta}_{\mathrm{i}, \mathrm{Fk}}$ are the independent variables and they remain the same for every regression. Only the dependent variables varies in each period.

This can also be expressed in a matrix notation:

$$
R_{t}=\hat{\beta} \gamma_{t}
$$

Where $R_{t}$ is an $n \times 1$ vector of average asset or portfolio returns, $\hat{\beta}$ is an $n x(m+1)$ vector of factor loadings where all the elements in the first column are $1, \gamma$ is an $(m+1) \times 1$ vector of premia where all elements in the first raw are the intercept $\alpha$.

To calculate a single risk premium for each factor, all the $\gamma_{\mathrm{j}, \mathrm{t}}$ terms are averaged into a single $\gamma_{\mathrm{j}}$. To calculate standard errors for the $\gamma_{\mathrm{j}}$ terms, each $\gamma_{\mathrm{j}, \mathrm{t}}$ observation is treated as an independent observation and a t-statistic calculated.

The t-statistic to test whether $\gamma_{\mathrm{j}}$ is different from 0 (zero) is expressed as:

$$
\frac{\gamma_{j}}{\sigma_{\gamma j} / \sqrt{T}}
$$

Where $\sigma_{\gamma \mathrm{j}}$ is the standard deviation of the $\gamma_{\mathrm{j}, \mathrm{t}}$ terms (this assumes asset returns are roughly independently identically distributed).

The $\gamma_{\mathrm{k}}$ coefficients the factor premium for an exposure with a $\hat{\beta}_{\mathrm{i}, \mathrm{Fk}}$ of 1 to factor $\mathrm{F}_{\mathrm{k}}$.

\subsection{Some Challenges and Proposed Solutions}

The main challenge documented in literature for the FMB procedure is the problem of estimation errors in the $\beta_{\mathrm{i}}$ estimates. Literature recommends creation of portfolios based on the notion that portfolio $\beta_{\mathrm{p}}$ will be less affected by measurement error than individual $\beta_{\mathrm{i}} \mathrm{s}$ '. However, Ang, Liu, and Schwarz (2016) provide both analytical and empirical evidence that smaller standard deviations of portfolio beta estimates do not lead to smaller standard errors of cross-sectional coefficient estimates.

Pasquariello (1999) proposes a small variant of the FMB procedure that utilize individual stock betas $\left(\beta_{\mathrm{i}}\right)$ and report similar results as FMB results with the same data set. Shanken (1992) proposes the adjustment of the standard errors. However, Borys (2007) uses individual stock betas $\left(\beta_{i}\right.$ 's) to explore for a model that can explain stock returns for the Visegrad countries with similar or less sample size to that of Kenya.

Other challenges are the identification of the market proxy and serial correlation problems. However, Low \& Nayak (2005) shows that the choice of the market portfolio is irrelevant for the validity of CAPM. Bartholdy and Peare (2003) shows that FMB procedure give unbiased estimates of the expected return even though a proxy is used for the market portfolio. 
Nonetheless, this study attempts the portfolio beta $\beta_{p}$ estimates approach as a robustness check. The Durbin-Watson (D-W) and Breusch -Godfrey (B-G) tests are used to check for serial correlation. Given the limited number of listed firms in Kenya, this study creates 6 portfolios based on size following the Chen et al. (1986) approach.

\section{The Study Findings and Discussions}

\subsection{Descriptive Statistics}

This study sought to examine the factors that determine stock returns for the emerging market of Kenya. The summary statistics are presented in Table 2 .

The ERm has a mean of -0.102 , a standard deviation of 0.092, a minimum of -0.349 and a maximum of 0.243 . The mean $\triangle$ CPI is 0.006 with a standard deviation of 0.011 , a minimum of -0.025 and a maximum of 0.051 . $\Delta \mathrm{EX}$ has a mean of 0.002 , a standard deviation of 0.023 , a minimum of -0.084 and a maximum of $0.157 . \Delta \mathrm{Ms}$ has a mean of 0.009 , a standard deviation of 0.013 , a minimum of -0.049 and a maximum of 0.066 . Finally, $\triangle$ ATB has a mean of 0.004 , a standard deviation of 0.171 , a minimum of -1.0 and a maximum of 0.694 . The mean and standard deviations of the excess returns for individual stocks are as shown in Table 2.

Table 2. Descriptive statistics

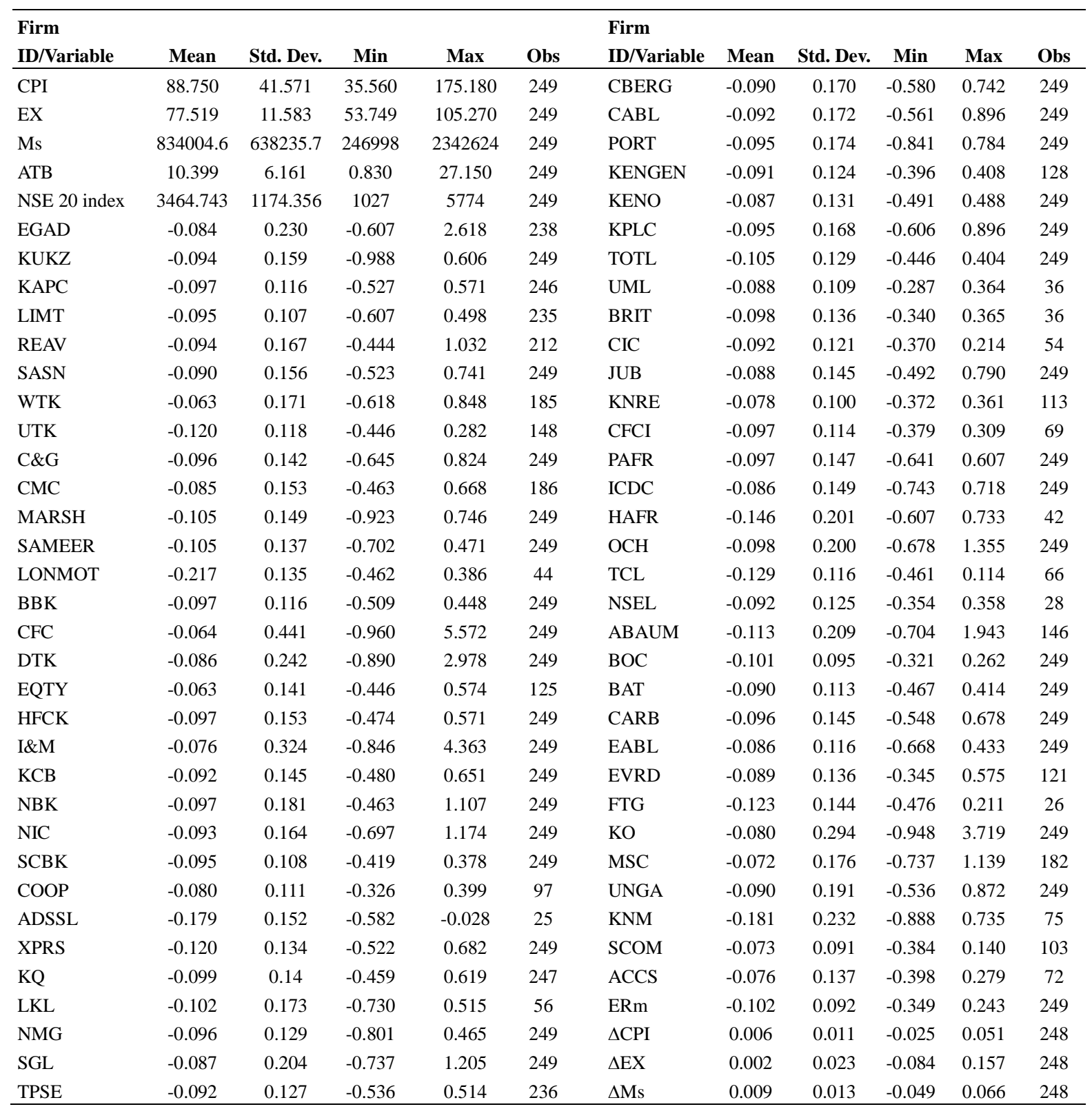




\begin{tabular}{|c|c|c|c|c|c|c|c|c|c|c|c|}
\hline UCHM & -0.106 & 0.133 & -0.475 & 0.578 & 249 & $\triangle \mathrm{ATB}$ & 0.004 & 0.171 & -1.000 & 0.694 & 249 \\
\hline SCAN & -0.075 & 0.131 & -0.419 & 0.509 & 125 & & & & & & \\
\hline EAPACK & -0.180 & 0.155 & -0.664 & 0.368 & 80 & & & & & & \\
\hline ARM & -0.080 & 0.138 & -0.611 & 0.498 & 233 & & & & & & \\
\hline BAMB & -0.093 & 0.113 & -0.437 & 0.305 & 249 & & & & & & \\
\hline
\end{tabular}

Source: Summary from Data analysis.

\subsection{Test for Stationary, Collinearity, Serial Correlation and Heteroskedasticity}

This study is based on a time series data, and therefore utilizes approaches that address technicalities of time series. Unit roots were tested using three common approaches: the Augmented Dickey Fuller (ADF), Phillips Perron (PP), and Kwiatkowski -Phillips -Schmidt -Shin (KPSS). These tests established the time series to be stationary and are integrated at order 1(0) (Note 2).

Time series regression assumptions allows for the independent variables to be correlated to some extent, but rules out perfect correlation. The Pearson correlations test is used to check for collinearity and the results are presented in Table 3.

Table 3. Test for correlations in independent variables

\begin{tabular}{lccccc}
\hline \multicolumn{5}{c}{ Pearson Correlation Coefficients test } \\
\hline Variables & $\mathrm{ER}_{\mathrm{m}}$ & $\Delta \mathrm{CPI}$ & $\Delta \mathrm{EX}$ & $\Delta \mathrm{Ms}$ & $\Delta \mathrm{ATB}$ \\
\hline $\mathrm{ER}_{\mathrm{m}}$ & 1.000 & & & & \\
$\Delta \mathrm{CPI}$ & 0.049 & 1.000 & & & \\
& $(0.439)$ & & & \\
$\Delta \mathrm{EX}$ & -0.037 & -0.097 & 1.000 & & \\
& $(0.567)$ & $(0.127)$ & & & \\
$\Delta \mathrm{Ms}$ & $0.153^{*}$ & 0.023 & 0.064 & 1.000 & \\
& $(0.016)$ & $(0.718)$ & $(0.318)$ & & \\
$\Delta \mathrm{ATB}$ & 0.092 & 0.074 & $0.155^{*}$ & -0.084 & $(0.184)$ \\
& $(0.150)$ & $(0.243)$ & $(0.014)$ & & \\
\hline
\end{tabular}

Note. * Implies significant at 0.05 and below confidence levels.

The $\Delta \mathrm{CPI}$ indicate a positive but insignificant correlation with the ERm. $\Delta \mathrm{EX}$ have a negative but insignificant correlation with both the ERm and $\Delta \mathrm{CPI}$. $\Delta \mathrm{Ms}$ has a significant positive correlation with the ERm but positive insignificant correlations with both $\triangle \mathrm{CPI}$ and $\Delta \mathrm{EX}$. Finally, the $\Delta$ ATB have a positive and significant correlation with changes in $\triangle \mathrm{EX}$, a positive but insignificant correlation with both the ERm and $\triangle \mathrm{CPI}$ and a negative insignificant correlation with $\Delta$ Ms. Overall, it is thus safe to assume that there is no perfect collinearity among the independent variables.

Tests for serial correlation were done using both the D-W 1950 test and the B-G test. The D-W d-statistics test for serial correlation in the residues of a linear regression while the $\mathrm{B}-\mathrm{G}$ test for higher -order serial correlation in the disturbance. The D-W d-statistics 5\% upper and lower bounds were obtained from Savin and White (1977) tables for 5 factors excluding the constant. The B-G p-values are observed at the $95 \%$ confidence levels. The Engle's Lagrange Multiplier (LM) is used to test for the autoregressive conditional heteroskedasticity in the FMB first step estimates. The LM test the null $\mathrm{H}_{0}$ : no ARCH effects against the $\mathrm{H}_{1}$ : $\mathrm{ARCH}(\mathrm{p})$ disturbance at the 5\% significance level. The serial correlation and heteroskedasticity results are presented in Table 4.

The D-W d-statistic tests the null $\mathrm{H}_{0}$ : no first-order autocorrelation. The null is rejected if the d-statistic is smaller than the 5\% lower bound, implying a positive serial correlation exists. If the d-statistic lies between the lower and upper bound, the test is considered inconclusive. If the d-statistic is larger than the upper bound, it implies negative serial correlation and the rule of the thump is to be conservative and not reject the null. From table 4 , the d-statistic tests out-rightly rejects the null for only one firm, is inconclusive for one firm and we cannot reject the null for the other 65 firms.

The B-G test the null $\mathrm{H}_{0}$ : no serial correlation. From table 4, the test rejects the null for $23.9 \%$ and fails to reject the null for $76.1 \%$ of the firms at lag (12), 5\% confidence level. Taken together, the two tests only reject the null for one firm, and thus can conclude there is no serial correlation problem with the time series. 
Based LM test, we cannot reject the null for $88.1 \%$ (59 listed firms) compared to 11.9 (8 listed firms) at either the default lags (1) level or at a lag 12. Therefore, we can presume the assumption for homoskedasticity to largely hold for the time series.

Table 4. Test for serial correlation and heteroskedasticity

\begin{tabular}{|c|c|c|c|c|c|c|c|c|c|c|c|}
\hline \multicolumn{12}{|c|}{ Test for Serial Correlations and Autoregressive Conditional Heteroskedasticity } \\
\hline \multirow[b]{2}{*}{ Firm ID } & \multirow{2}{*}{$\frac{\text { D -W test }}{\text { d-stats }}$} & \multicolumn{2}{|c|}{ B-G test } & \multicolumn{2}{|c|}{ LM test } & \multirow[b]{2}{*}{ Firm ID } & \multirow{2}{*}{$\begin{array}{c}\text { D -W test } \\
\text { d-stats }\end{array}$} & \multicolumn{2}{|c|}{ B-G test } & \multicolumn{2}{|c|}{ LM test } \\
\hline & & Chi2 & P-values & Chi2 & P-values & & & Chi2 & P-values & Chi2 & P-values \\
\hline EGAD & 2.154 & 6.535 & 0.887 & 0.054 & 0.816 & BAMB & 2.184 & 8.273 & 0.763 & 1.413 & 0.235 \\
\hline KUKZ & 2.556 & 31.071 & $0.002 *$ & $9.385 \square$ & 0.670 & CBERG & 2.465 & 27.861 & $0.006^{*}$ & $24.576 \square$ & $0.017 *$ \\
\hline KAPC & 1.949 & 16.716 & 0.161 & 0.092 & 0.762 & CABL & 1.147 & 16.353 & 0.176 & 1.147 & 0.284 \\
\hline LIMT & 1.931 & 12.569 & 0.401 & 0.210 & 0.647 & PORT & 2.379 & 12.601 & 0.399 & 1.419 & 0.234 \\
\hline REAV & 2.542 & 39.457 & $0.000 *$ & 3.431 & 0.064 & KENGEN & 2.604 & 22.026 & $0.037 *$ & $4.229 \square$ & 0.979 \\
\hline SASN & 2.039 & 22.569 & $0.032 *$ & 22.772 & $0.000^{*}$ & KENO & 2.349 & 19.118 & 0.086 & 1.382 & 0.240 \\
\hline WTK & 2.196 & 20.604 & 0.052 & 0.200 & 0.655 & KPLC & 2.047 & 18.655 & 0.097 & $54.294 \square$ & $0.000 *$ \\
\hline UTK & $1.521 * *$ & 38.962 & $0.000 *$ & 1.296 & 0.255 & TOTL & 2.143 & 8.487 & 0.746 & 1.231 & 0.267 \\
\hline$C \& G$ & 2.061 & 13.281 & 0.349 & 0.000 & 0.989 & UML & 1.994 & 4.891 & 0.962 & 0.223 & 0.637 \\
\hline $\mathrm{CMC}$ & 1.814 & 11.620 & 0.477 & 1.556 & 0.212 & BRIT & 2.167 & 8.078 & 0.779 & 1.786 & 0.181 \\
\hline MARSH & 2.047 & 10.761 & 0.550 & 0.719 & 0.397 & CIC & 1.833 & 8.075 & 0.779 & 0.439 & 0.508 \\
\hline SAMEER & 2.439 & 22.078 & $0.037 *$ & $5.010 \square$ & 0.171 & JUB & 2.439 & 27.973 & $0.006^{*}$ & 0.347 & 0.556 \\
\hline LONMOT & 2.321 & 9.972 & 0.618 & 0.006 & 0.940 & KNRE & 1.899 & 9.973 & 0.618 & $11.234 \square$ & 0.509 \\
\hline $\mathrm{BBK}$ & 2.349 & 22.021 & $0.037 *$ & $19.711 \square$ & 0.073 & CFCI & 1.820 & 8.548 & 0.741 & 2.081 & 0.149 \\
\hline $\mathrm{CFC}$ & 2.312 & 7.679 & 0.810 & 0.136 & 0.713 & PAFR & 1.998 & 4.609 & 0.970 & 2.210 & 0.137 \\
\hline DTK & 2.391 & 11.368 & 0.498 & 1.304 & 0.253 & ICDC & 1.992 & 11.225 & 0.510 & 0.893 & 0.345 \\
\hline EQTY & 1.720 & 16.138 & 0.185 & 0.146 & 0.702 & HAFR & 2.102 & 3.303 & 0.993 & 0.029 & 0.864 \\
\hline HFCK & 2.358 & 26.515 & $0.009 *$ & 26.218 & $0.010^{*}$ & $\mathrm{OCH}$ & 2.288 & 15.694 & 0.206 & 0.451 & 0.502 \\
\hline $\mathrm{I} \& \mathrm{M}$ & 2.290 & 7.570 & 0.818 & 0.208 & 0.648 & TCL & 1.564 & 7.431 & 0.828 & 0.232 & 0.630 \\
\hline $\mathrm{KCB}$ & 2.061 & 13.816 & 0.313 & 2.949 & 0.086 & NSEL & 2.040 & 4.328 & 0.977 & 1.359 & 0.244 \\
\hline NBK & 2.054 & 16.474 & 0.171 & 1.238 & 0.266 & ABAUM & 2.080 & 4.040 & 0.983 & 0.002 & 0.963 \\
\hline NIC & 2.575 & 31.123 & $0.002 *$ & $11.886 \square$ & 0.455 & BOC & 1.779 & 32.948 & $0.001^{*}$ & 1.302 & 0.310 \\
\hline SCBK & 2.472 & 21.136 & $0.048 *$ & 36.464 & $0.000^{*}$ & BAT & 2.238 & 20.796 & 0.053 & $13.419 \square$ & 0.339 \\
\hline COOP & 2.183 & 11.710 & 0.469 & 1.358 & 0.244 & CARB & 2.219 & 11.797 & 0.462 & 44.593 & $0.000^{*}$ \\
\hline XPRS & 2.283 & 11.498 & 0.487 & 1.377 & 0.241 & EABL & 2.450 & 28.631 & $0.005^{*}$ & $44.93 \square$ & $0.000 *$ \\
\hline KQ & 1.687 & 22.217 & $0.035^{*}$ & 0.625 & 0.429 & EVRD & 2.240 & 11.393 & 0.496 & 2.960 & 0.085 \\
\hline LKL & 1.836 & 4.595 & 0.970 & 0.535 & 0.464 & FTG & 1.878 & 13.395 & 0.341 & 0.554 & 0.457 \\
\hline NMG & 2.156 & 18.271 & 0.108 & 19.403 & 0.079 & $\mathrm{KO}$ & $1.241 * * *$ & 68.05 & $0.000 *$ & 11.767 & 0.465 \\
\hline SGL & 2.277 & 18.271 & 0.108 & 1.948 & 0.163 & MSC & 1.995 & 6.44 & 0.892 & 0.078 & 0.78 \\
\hline TPSE & 2.346 & 14.392 & 0.276 & 3.745 & 0.053 & UNGA & 2.344 & 14.476 & 0.271 & 0.160 & 0.689 \\
\hline UCHM & 2.152 & 12.014 & 0.445 & 0.908 & 0.341 & KNM & 1.867 & 13.469 & 0.336 & 0.180 & 0.671 \\
\hline SCAN & 2.308 & 12.096 & 0.438 & 3.086 & 0.079 & SCOM & 1.921 & 9.203 & 0.686 & 2.355 & 0.125 \\
\hline EAPACK & 2.225 & 14.178 & 0.290 & 0.441 & 0.506 & ACCS & 1.384 & 14.851 & 0.25 & 11.984 & 0.447 \\
\hline ARM & 2.020 & 12.406 & 0.414 & $25.921 \square$ & $0.011^{*}$ & & & & & & \\
\hline
\end{tabular}

Note. $*$ Implies test is significant at 0.05 confidence levels; ** implies d-stats test is inconclusive; *** implies d-stats less than the lower $5 \%$ bound; $\square$ Implies test at higher lag (12) as opposed to the default lag (1).

\subsection{CAPM Test Results}

The validity of CAPM test results are presented in Table 5. They indicate that the market premium coefficient ( $\beta$ ) is statistically significant for all individual stocks except for two firms. The constant is only significant at various degrees of confidence levels for 15 out of the 67 listed firms and insignificant for 52 out of the 67 listed firms over the period. Therefore, $\beta$ explains the variability of stock returns for at least $77.6 \%$ of the listed firms. A significant constant for the remaining $22.4 \%$ firms implies part of the variability in these stocks could be explained by other factors, other than $\beta$.

Based on these results, we cannot therefore reject the validity of the CAPM in Kenya. 
Table 5. CAPM test results

\begin{tabular}{|c|c|c|c|c|c|c|c|c|c|c|c|}
\hline Firm ID & $\boldsymbol{\beta}$ & t-stats & $\mathbf{R}^{2}$ & Adj. $\mathbf{R}^{2}$ & $\alpha^{*}$ & Firm ID & $\boldsymbol{\beta}$ & t-stats & $\mathbf{R}^{2}$ & Adj. $R^{2}$ & $\alpha^{*}$ \\
\hline EGAD & $0.735^{* * *} *$ & $(4.63)$ & 0.0834 & 0.0795 & -0.013 & CBERG & $0.902 * * *$ & $(8.75)$ & 0.2365 & 0.2334 & 0.002 \\
\hline KUKZ & $0.899 * * *$ & (9.53) & 0.2689 & 0.2660 & -0.002 & CABL & $1.054 * * *$ & (10.65) & 0.3145 & 0.3118 & 0.015 \\
\hline KAPC & $0.541 * * *$ & (7.37) & 0.1822 & 0.1788 & $-0.042 * * *$ & PORT & $0.808 * * *$ & $(7.39)$ & 0.1809 & 0.1776 & -0.013 \\
\hline LIMT & $0.489 * * *$ & $(6.88)$ & 0.1690 & 0.1654 & $-0.049 * * *$ & KENGEN & $1.123 * * *$ & $(8.68)$ & 0.3792 & 0.3692 & 0.002 \\
\hline REAV & $1.095 * * *$ & (11.97) & 0.4055 & 0.4027 & 0.017 & KENO & $0.830 * * *$ & (11.26) & 0.3393 & 0.3366 & -0.002 \\
\hline SASN & $0.929 * * *$ & (10.23) & 0.2974 & 0.2946 & 0.004 & KPLC & $1.149 * * *$ & $(12.71)$ & 0.3954 & 0.3929 & $0.022 *$ \\
\hline WTK & $0.809 * * *$ & $(5.43)$ & 0.1390 & 0.1343 & -0.005 & TOTL & $0.924 * * *$ & (13.69) & 0.4314 & 0.4291 & -0.011 \\
\hline UTK & $0.240 * *$ & (2.17) & 0.0312 & 0.0245 & $-0.102 * * *$ & UML & 0.338 & $(0.91)$ & 0.0237 & 0.0051 & -0.053 \\
\hline$C \& G$ & $0.690 * * *$ & (7.79) & 0.1971 & 0.1938 & -0.025 & BRIT & $1.127 * *$ & $(2.63)$ & 0.1691 & 0.1447 & 0.021 \\
\hline CMC & $0.924 * * *$ & (10.5) & 0.3746 & 0.3712 & 0.009 & CIC & $1.449 * * *$ & $(5.10)$ & 0.3335 & 0.3207 & 0.046 \\
\hline MARSH & $0.638 * * *$ & $(6.69)$ & 0.1532 & 0.1498 & $-0.04 * * *$ & JUB & $1.060 * * *$ & (14.32) & 0.4501 & 0.4479 & $0.020 *$ \\
\hline SAMEER & $0.956 * * *$ & (13.03) & 0.4074 & 0.4050 & -0.008 & KNRE & $0.951^{* * *}$ & $(8.93)$ & 0.4180 & 0.4127 & 0.006 \\
\hline LONMOT & $0.737 * * *$ & $(2.76)$ & 0.1533 & 0.1331 & -0.064 & CFCI & $0.935^{* * *} *$ & $(4.05)$ & 0.1970 & 0.1850 & -0.001 \\
\hline $\mathrm{BBK}$ & $0.988 * * *$ & (19.58) & 0.6082 & 0.6066 & 0.004 & PAFR & $0.867 * * *$ & (10.13) & 0.2937 & 0.2908 & -0.009 \\
\hline $\mathrm{CFC}$ & $1.216 * * *$ & $(4.11)$ & 0.0640 & 0.0602 & 0.06 & ICDC & $1.022 * * *$ & $(12.72)$ & 0.3959 & 0.3935 & $0.018^{*}$ \\
\hline DTK & $1.023 * * *$ & $(6.62)$ & 0.1507 & 0.1473 & 0.019 & HAFR & $1.159^{*}$ & $(1.85)$ & 0.0791 & 0.0561 & -0.028 \\
\hline EQTY & $1.271 * * *$ & $(8.57)$ & 0.3740 & 0.3689 & $0.044 * * *$ & $\mathrm{OCH}$ & $0.969^{* * *}$ & (7.78) & 0.1968 & 0.1935 & 0.001 \\
\hline HFCK & $1.144 * * *$ & (14.78) & 0.4695 & 0.4673 & $0.020^{*}$ & TCL & $0.729 * * *$ & (2.84) & 0.1122 & 0.0983 & $-0.052 *$ \\
\hline $\mathrm{I} \& \mathrm{M}$ & $0.993 * * *$ & $(4.60)$ & 0.0788 & 0.0750 & 0.026 & NSEL & 0.471 & (1.06) & 0.0413 & 0.0045 & -0.039 \\
\hline $\mathrm{KCB}$ & $1.211^{* * *}$ & (18.86) & 0.5901 & 0.5884 & $0.032 * * *$ & ABAUM & $0.722 * * *$ & $(4.64)$ & 0.1302 & 0.1241 & -0.033 \\
\hline NBK & $1.249 * * *$ & (12.83) & 0.4000 & 0.3976 & $0.030 * *$ & BOC & $0.667 * * *$ & (13.18) & 0.4129 & 0.4105 & $-0.033 * * *$ \\
\hline NIC & $1.096 * * *$ & $(12.21)$ & 0.3763 & 0.3737 & 0.019 & BAT & $0.807 * * *$ & $(13.56)$ & 0.4267 & 0.4244 & -0.007 \\
\hline SCBK & $0.865 * * *$ & $(16.9)$ & 0.5363 & 0.5344 & -0.007 & CARB & $0.803 * * *$ & $(9.30)$ & 0.2594 & 0.2564 & -0.014 \\
\hline $\mathrm{COOP}$ & $1.178 * * *$ & $(9.76)$ & 0.5004 & 0.4952 & 0.021 & EABL & $0.813 * * *$ & (13.24) & 0.4152 & 0.4129 & -0.004 \\
\hline XPRS & $0.785 * * *$ & $(9.98)$ & 0.2875 & 0.2846 & $-0.03 * * *$ & EVRD & $0.808 * * *$ & $(4.70)$ & 0.1564 & 0.1494 & -0.019 \\
\hline KQ & $0.979 * * *$ & (12.99) & 0.4077 & 0.4053 & 0 & FTG & $1.522 * * *$ & $(3.48)$ & 0.3356 & 0.3079 & 0.05 \\
\hline LKL & $0.943^{*}$ & $(1.97)$ & 0.0672 & 0.0499 & -0.012 & $\mathrm{KO}$ & $0.626 * * *$ & $(3.13)$ & 0.0381 & 0.0342 & -0.016 \\
\hline NMG & $0.796 * * *$ & (10.76) & 0.3191 & 0.3164 & -0.015 & MSC & $1.142 * * *$ & (7.89) & 0.2568 & 0.2526 & 0.008 \\
\hline SGL & $0.954 * * *$ & $(7.48)$ & 0.1846 & 0.1813 & 0.01 & UNGA & $0.896 * * *$ & (7.48) & 0.1848 & 0.1815 & 0.002 \\
\hline TPSE & $0.937 * * *$ & (13.52) & 0.4386 & 0.4362 & -0.002 & KNM & $1.451 * * *$ & $(4.04)$ & 0.1824 & 0.1712 & 0.083 \\
\hline UCHM & $0.637 * * *$ & $(7.66)$ & 0.1918 & 0.1885 & $-0.041 * * *$ & SCOM & $0.947 * * *$ & (10.0) & 0.4977 & 0.4928 & 0.012 \\
\hline SCAN & $1.116^{* * * *}$ & $(7.82)$ & 0.3321 & 0.3267 & 0.019 & ACCS & $1.147 * * *$ & $(6.87)$ & 0.4029 & 0.3943 & 0.013 \\
\hline EAPACK & $0.988 * * *$ & $(4.62)$ & 0.2145 & 0.2044 & -0.008 & & & & & & \\
\hline $\mathrm{ARM}$ & $0.951 * * *$ & (11.98) & 0.3832 & 0.3805 & 0.01 & & & & & & \\
\hline BAMB & $0.807^{* * * *}$ & $(13.62)$ & 0.429 & 0.4267 & -0.01 & & & & & & \\
\hline
\end{tabular}

Note. $* * *$ implies significant at the $1 \%$ level; ** implies significant at the $5 \%$ level; * implies significant at the $10 \%$ level; $\alpha *$ is a check as to whether the constant is significant.

\subsection{The FMB Procedure Results}

The FMB procedure is a two-step process to determine if some identified risk factors are priced in stock returns. The single risk premium for each of the factors $\left(\gamma_{\mathrm{j}}\right)$ is the average of all the $\gamma_{\mathrm{j}, \mathrm{t}} \mathrm{T}$ - statistics are used to test if the single risk premiums are different from zero (Note 3 ).

The average single risk premiums for each factor and their t-test are presented in Table 6 .

Table 6. FMB test results

\begin{tabular}{lcccccc}
\hline \multicolumn{7}{c}{ The FMB Test Results } \\
\hline Variable & Mean & Variance & Std. Dev & t-stats & Critical t-value & p-values \\
\hline $\mathrm{ER}_{\mathrm{m}}$ & 0.022042 & 0.026721 & 0.163467 & 2.1278 & 1.651 & 0.017 \\
$\Delta \mathrm{CPI}$ & -0.0016 & 0.000846 & 0.029088 & -0.8664 & 1.651 & 0.194 \\
$\Delta \mathrm{EX}$ & 0.000252 & 0.003694 & 0.060779 & 0.0654 & 1.651 & 0.474 \\
$\Delta \mathrm{Ms}$ & -0.02099 & 0.102106 & 0.31954 & -1.0364 & 1.651 & 0.151 \\
$\Delta \mathrm{ATB}$ & -0.01924 & 0.235675 & 0.485464 & -0.6254 & 1.651 & 0.266 \\
\hline
\end{tabular}


The t-statistics test the following hypothesis:

$\mathrm{H}_{0}: \gamma_{\mathrm{j}}$ is not different from zero.

$\mathrm{H}_{1}: \gamma_{\mathrm{j}}$ is different from zero.

The t-statistics for the market premium is 2.1278 and is greater than the one- tail critical t-value (1.651) and the p-value is 0.017 which is lower than 0.05 values (95\% confidence levels). Thus, we can reject the $\mathrm{H}_{0}$ in favour of the alternative $\mathrm{H}_{1}$. This implies that the market risk premium is different from zero and hence priced in stock returns in the Kenyan market.

The t-statistics for $\Delta \mathrm{CPI}, \Delta \mathrm{EX}, \Delta \mathrm{Ms}$ and $\Delta \mathrm{ATB}$ are $-0.8664,0.0654,-1.0364$ and -0.6254 respectively and all are less than the critical t-value (1.651). Similarly, the P-values for the 4 factors are 0.194, 0.474, 0.151 and 0.266 respectively and greater than 0.05 (95\% confidence level). Thus, the $\mathrm{H}_{0}$ for $\Delta \mathrm{CPI}, \Delta \mathrm{EX}, \Delta \mathrm{Ms}$ and $\Delta \mathrm{ATB}$ cannot be rejected for these factors. This implies that these factors are not important in determining stock returns.

\subsection{Robustness Checks}

As a robustness check for the individual firm results, six portfolios are constructed and tested for both CAPM and the FMB procedure. The portfolios were constructed based on size (market value). The portfolios are reconstructed at the begging of April (closing prices on last trading day of March * No. of listed shares) for every year. The excess portfolio returns are computed using a simple average. The portfolios are in ascending order with portfolio one constituting smallest firms and portfolio six the largest firms.

The CAPM estimates are presented in Table 7.

Table 7. Portfolio CAPM test

\begin{tabular}{cccccc}
\hline \multicolumn{7}{c}{ CAPM test results for Portfolio Excess returns } \\
\hline Portfolio & $\boldsymbol{\beta}$ & t-stats & $\mathbf{R}^{\mathbf{2}}$ & Adj. $\mathbf{R}^{\mathbf{2}}$ & A \\
\hline 1 & $0.723^{* * *}$ & $(8.77)$ & 0.2375 & 0.2344 & $-0.021^{*}$ \\
2 & $0.896^{* * *}$ & $(14.38)$ & 0.4557 & 0.4535 & 0.01 \\
3 & $0.900^{* * *}$ & $(18.46)$ & 0.5799 & 0.5782 & 0.001 \\
4 & $0.904 * * *$ & $(18.76)$ & 0.5875 & 0.5859 & -0.001 \\
5 & $0.884^{* * *}$ & $(23.03)$ & 0.6823 & 0.681 & -0.007 \\
6 & $0.924 * * *$ & $(30.76)$ & 0.793 & 0.7922 & 0.004 \\
\hline
\end{tabular}

Note. ${ }^{* * *}$ implies significant at $1 \%$ confidence level; * implies significant at $10 \%$ confidence level; $\alpha$ is the constant.

Again the market premium is positive and significant for all portfolios and the constants insignificant except for small cap firms' portfolio. Therefore, CAPM cannot be rejected. However, the FMB procedure was inconclusive as the second step could not be completed due the small number of observations.

\section{Conclusions}

This study set out to examine the determinants of stock returns in the emerging stock market of Kenya. The study finds that CAPM cannot be rejected based on test results for both individual stocks and portfolios constructed based on size. Further results indicate the market premium is the most important determinant of stock returns for listed firms at the NSE.

Tests using the FMB procedure indicate that excess market premium is the most important risk factor priced in stock returns in Kenya. The evidence for the macroeconomic factors suggests that they are unimportant, at least in terms of statistical significance. Since we cannot reject the CAPM, then the betas ( $\beta$ 's) presented in Table 5, can be taken as risk premiums for individual firms listed at the NSE.

However, the limitations of this study cannot be overlooked since only selected factors have been examined. Further research would be necessary to examine other factors such as momentum, liquidity premium and factors of attribute documented in other emerging and advanced markets, if and as data will allow.

\section{Acknowledgement}

This article is one part of my thesis submitted for the award of a $\mathrm{PhD}$ (Economics) -Finance degree at the Central University of Finance and Economics (CUFE), Beijing, China. Therefore, i wish to take this opportunity to register my appreciation to my academic supervisor, Prof. Zhang Xueyong and the various defense panelist in which the thesis was presented during the examination process. The various comments and inputs have contributed a lot in shaping the final version of this article. 


\section{References}

Al-Rjoub, S. A. M., Yousef, A. Al., \& Ananzeh, I. E. (2010). Beta Wins Again: Case of four Emerging Markets. Journal of Economic Cooperation and Development, 31(1), 1-16.

Ang, A., Liu, J., \& Schwarz, K. (2016). Using Stock or Portfolios in Tests of Factor Models. Paper presented at the American Finance Association, Columbia University, October 2016. http://dx.doi.org/10.2139/ssrn.1106463

Aroni, J. M. (2011). Factors Influencing Stock Prices for Firms Listed in the Nairobi Stock Exchange. International Journal of Business and Social Science, 2(20).

Artmann, S., Finter, P., \& Kempf, A. (2011). Determinants of Expected Stock Returns: Large Sample Evidence from the Germany Market. CFR-Working Paper No. 10-01. https://doi.org/10.2139/ssrn.1653747

Aurangzeb. (2012). Factors Affecting Performance of Stock Markets: Evidence from South Asian Countries. International Journal of Academic Research in Business and Social Sciences, 2(9).

Bartholdy, J., \& Peare, P. (2003). Unbiased Estimation of Expected Returns using CAPM. International Review of Financial Analysis, 12, 69-81. https://doi.org/10.1016/S1057-5219 (02)00122-9

Benakovic, D., \& Posedel, P. (2010). Do Macroeconomic Factors Matter for Stock Returns? Evidence from Estimating a Multifactor Model on the Croatian Market. Working Paper Series, paper No. 10-12. https://doi.org/10.2478/v10305-012-0023-z

Borys, M. M. (2007). Testing Multi-Factor Asset Pricing Models in the Visegrad Countries. CERGI-EI, Working Paper Series 323 (ISSN 1211 -3298), March 2007, Electronic version.

Brennan, M. J. (1970). Investor Taxes, Market Equilibrium and Corporation Finance. National Tax Journal, 3(3), 417-429.

Carhart, M. M. (1997). On Persistence in Mutual Fund Performance. Journal of Finance, 52(1), 57-82. https://doi.org/10.1111/j.1540-6261.1997.tb03808.x

Chen, N., Roll, R., \& Ross, S.A. (1986). Economic Forces and the Stock Market. Journal of Business, 59, 383 -403. http://dx.doi.org/10.1086/296344

Dasgupta, S., \& Glen, J. (1999). The Cross section of Stock Returns: Evidence from Emerging Markets. World Bank Policy Research Working papers. http://dx.doi.org/10.1596/1813-9450-1505

Eita, J. H. (2011). Determinants of Stock Market Prices in Namibia. Working paper no. 209, Monash University, South Africa.

Ericsson, J., \& Karlsson, S. (2004). Choosing Factors in a Multifactor Asset Pricing Model: A Bayesian Approach. Stockholm School of Economics, SSE/EFI Working Paper Series in Economics and Finance No. 524, February 2004.

Fama, E. F., \& French, K. R. (1992). The Cross-Section of Expected Stock Returns. Journal of Finance, 47, 427-465. https://doi.org/10.1111/j.1540-6261.1992.tb04398.x

Fama, E. F., \& French, K. R. (1993). Common Risk Factors in the Returns of Stocks and Bonds. Journal of Financial Economics, 33, 3-56. https://dx.doi.org/10.1016/0304-405X(93)90023-5

Fama, E. F., \& French, K. R. (1998). Value versus Growth: The International Evidence. The Journal of Finance, L111(6). https://doi.org/10.1111/0022-1082.00080

Fama, E. F., \& French, K. R. (2015). A five-factor Asset pricing model. Journal of Financial Economics, 116(2015), 1-22. https://dx.doi.org/10.1016/j.jfineco.2014.10.010

Fama, E. F., \& MacBeth, J. D. (1973). Risk, Return and Equilibrium: Empirical Tests. Journal of Political Economy, 81, 607-636. https://doi.org/10.1086/260061

Gituhi, S., Gekara, M., \& Muturi, W. (2015). Effect of Macroeconomic Environment on Stock Market Returns for Firms in the Agricultural Sector in Kenya. International Journal of Management and Business Studies, 5(3), September 2015.

Hsu, J. C. (2015). Fama MacBeth Estimation. A presentation at Anderson MFE program.

Kiboi, J., \& Katuse, P. (2015). Nairobi Stock Exchange: A Regression of Factors Affecting Stock Prices. Prime Journal of Social Science, 4(6), 1093-1098.

Kimani, D. K., \& Mutuku, C. M. (2013). Inflation Dynamics in the Overall Stock Market Performance: The 
Case of Nairobi Securities Exchange in Kenya. Economics and Finance Review 2(11), 1-11.

Kirui, E., Wawire, N. H. W., \& Onono, P. O. (2014). Macroeconomic Variables, Volatility and Stock market Returns: A Case of Nairobi Securities Exchange, Kenya. International Journal of Economics and Finance, 6(8), 2014. http://dx.doi.org/10.5539/ijef.v6n8p214

Kumar, R. (2013). The Effect of Macroeconomic Factors on the Indian Stock Market Performance: A Factor Analysis Approach. Journal of Economics and Finance, 1(3), 14-21. https://doi.org/10.9790/5933-0131421

Laichena, K. E., \& Obwogi, T. N. (2015). Effects of Macroeconomic Variables on Stock Returns in the East African Community Stock Exchange Market. Journal of Education and Research 3(10), October 2015.

Lintner, J. (1965). The Valuation of Risk Assets and the Selection of Risky Investments in Stock Portfolios and Capital Budgets. Review of Economics and Statistics 47, 13-37. https://doi.org/10.2307/1924119

Lischewski, J., \& Voronkova, S. (2010). Size, Value and Liquidity: Do they Really Matter on an Emerging Market? ZEW Discussion Papers, No. 10-070. Center for European Economic Research.

Low, C., \& Nayak, S. (2005). The Non-Relevance of the Elusive Holy Grail of Asset Pricing Tests: the 'True' Market Portfolio Doesn't Really Matter. EFA 2005 Moscow Meetings Paper. Retrieved from http://ssrn.com/abstarct=675423

Mahonye, N., \& Mandishara, L. (2014). Stock Market Returns and Hyperinflation in Zimbabwe. Investment Management and Financial Innovations, II(4).

Maku, O. E., \& Atanda, A. A. (2010). Determinants of Stock Market Performance in Nigeria: A Long-Run Analysis. Journal of Management and Organization Behaviour, 1(3).

Menike, L. M. C. S., Dunusinghe, P. M., \& Ranasinghe, A. (2015). Macroeconomic and Firm Specific Determinants of Stock Returns: A Comparative Analysis of Stock Markets in Sri Lanka and in the United Kingdom. Journal of Finance and Accounting, 3(4), 86-96. https://doi.org/10.1164/j.jfa.20150304.14

Mossin, J. (1966). Equilibrium in Capital Asset Market. Econometrica, 34, 768-783. https://doi.org/10.2307/1910098

Muinde, P. M. (2017). Effects of Macroeconomic Volatility on Stock Prices in Kenya: A Co-integration Evidence from the Nairobi Securities Exchange (NSE). International Journal of Economics and Finance, 9(2). https://doi.org/10.5539/ijef.v9n2p1

Muinde, P. M., \& Karanja, J. M. (2017). Kenya Commercial Banks are Star Performers -Myth or Truth: Exploratory Empirical Evidence from the Nairobi Securities Exchange (NSE). International Journal of Economics and Financial Issues, 7(1), 340-350.

Naik, K. P., \& Padhi, P. (2012). The Impact of Macroeconomic Fundamentals on Stock Prices Revisited: Evidence from Indian data. Eurasian Journal of Business and Economics, 5(10), 25-44.

Ochieng, D. E., \& Oriwo, E. A. (2012). The Relationship between Macro-economic variables and Stock Market Performance in Kenya. DBA Africa Management Review, 3(1), 38-49.

Olowoniyi, A. O., \& Ojenike, J. O. (2012). Determinants of Stock Returns of Nigeria -Listed Firms. Journal of Emerging Trends in Economics and Management Science 3(4), 389-392.

Osisanwo, B. G., \& Atanda, A. A. (2012). Determinants of Stock Market Returns in Nigeria: A Time-Series Analysis. African Journal of Scientific Research, 9(1).

Ouma, W. N., \& Muriu, P. (2014). The Impact of Macroeconomic Variables on Stock Market Returns in Kenya. International Journal of Business and Commerce, 3(11).

Oyama, T. (1997). Determinants of Stock Prices: The Case of Zimbabwe. IMF Working paper WP/97/117. https://doi.org/10.5089/9781451941616.001

Pal, K., \& Mittal, R. (2011). Impact of Macroeconomic Indicators on Indian Capital Markets. Journal of Risk Finance, 12(2), 84-97. http://dx.doi.org/10.1108/15265941111112811

Pasquariello, P. (1999). The Fama MacBeth Approach Revisited. Unpublished PhD paper, Stern School of Business, New York University.

Patel, S. (2012). The Effect of Macroeconomic Determinants on the Performance of the Indian Stock Market. NMIMS Management Review, XXII.

Rouwenhorst, K. G. (1999). Local Factor and Turnover in Emerging Stock Markets. The Journal of Finance, 
LIV(4). https://doi.org/10.1111/0022-1082.00151

Serra, A. P. (2003). The Cross-Sectional Determinants of Returns: Evidence from Emerging Market's Stocks. Working papers da FEP no. 120, October 2002. https://doi.org/10.1177/097265270300200201

Shanken, J. (1992). On Estimation of Beta-Pricing Models. Review of Financial Studies, 5, 1-33. https://doi.org/10.1093/rfs/5.1.1

Sharpe, W. F. (1964). Capital Asset Prices: A Theory of Market Equilibrium under Conditions of Risk. Journal of Finance, 19, 425-422. https://doi.org/10.1111/j.1540-6261.1964.tb02865.x

\section{Notes}

Note 1. Includes M1 (defined as MO (Currency in circulation- Cash in bank till- Commerative coins) + other deposits at CBK + Demand deposits in Banks) + quasi money in banks and quasi money in Non Bank Financial Institutions (NBFI's)).

Note 2. Test results are available from the author on request.

Note 3. $1^{\text {st }}$ step regression $\&$ cross-sectional results are available from author on request.

\section{Copyrights}

Copyright for this article is retained by the author(s), with first publication rights granted to the journal.

This is an open-access article distributed under the terms and conditions of the Creative Commons Attribution license (http://creativecommons.org/licenses/by/4.0/). 